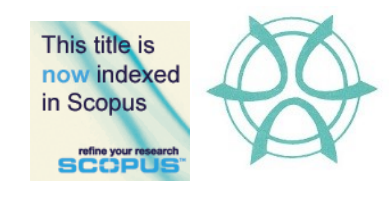

PLANNING MALAYSIA:

Journal of the Malaysian Institute of Planners

VOLUME 19 ISSUE 4 (2021), Page 280 - 291

\title{
THE INFLUENCE OF LAND USE ACTIVITIES TOWARDS MASS RAPID TRANSIT (MRT) FEEDER BUS SERVICE RIDERSHIP
}

\author{
Yakin Nur Sunoto ${ }^{1}$, Zakiah Ponrahono ${ }^{2}$, Zulfa Hanan Ash'aari ${ }^{3}$, Nur Aulia Rosni ${ }^{4}$, \\ Noor Suzilawati Rabe ${ }^{5}$, Nur Shazreena Mat Shukri', \\ Wan Noratikah Wahidah Wan Ghazali ${ }^{7}$ \\ 1,2,3,6,7 Department of Environment, Faculty of Forestry and Environment \\ UNIVERSITI PUTRA MALAYSIA \\ ${ }^{4}$ Department of Urban and Regional Planning, Faculty of Built Environment, \\ UNIVERSITI OF MALAYA \\ ${ }^{5}$ Department of Urban and Regional Planning, \\ Kulliyyah of Architecture and Environmental Design \\ INTERNATIONAL ISLAMIC UNIVERSITY MALAYSIA
}

\begin{abstract}
The Mass Rapid Transit (MRT) feeder bus service is a complementary public transport service provided to encourage ridership of MRT rail services in Malaysia. In brief, this feeder bus service plays a role in connecting people to and from MRT stations. The objective of this study is to determine the passenger volume generated at each MRT feeder bus stop location in the study area, and relate it to surrounding land use activities. Using the rule of thumb in public transportation systems, $200 \mathrm{~m}$ and $400 \mathrm{~m}$ radial buffers were identified as catchment areas of the bus stops. The key finding from this study is the relationship between volume of passenger and land use activities. This study concludes that land use activities influence MRT ridership, and that the presence of shelters or waiting poles is important to encourage ingress or egress.
\end{abstract}

Keywords: feeder bus, catchment area, land use activities, ridership

\footnotetext{
${ }^{2}$ Senior Lecturer at Universiti Putra Malaysia. Email: zakh@upm.edu.my
} 
PLANNING MALAYSIA

Journal of the Malaysia Institute of Planners (2021)

\section{INTRODUCTION}

Over the years, land use has significantly impacted traffic mobility (Zuo, Wei, \& Rohne, 2018), therefore, land use and transit planning must be coordinated simultaneously (Litman, 2008) because it can influence on people's habits, behaviour, culture, identity (Colonna, Berloco, \& Circella, 2012) and eventually mode choice (Vos, 2015). Normative practice of self-oriented transportation development has resulted in the lack of mutual, shared and interoperable transportation principles, leading to transfer difficulties and deficiency between various mode of transports (Chen, Shan, Ye, Yi, \& Wang, 2017). Thus, integration between bus and rail modes is important to ease the interchange between modes of transportation (Clifton \& Mulley, 2018) as some passengers use both services in one trip to their final destination (Ciaffi, Cipriani, \& Petrelli, 2012).

Despite the development and improvements of new and existing rail transits, however, huge challenges and limitations are still present as the ridership captured is not optimum (Hu, Zhang, \& Wang, 2012). Hence, the accessibility of an existing feeder network is an important determinant in yielding ridership (Tabassum, Tanaka, Nakamura, \& Ryo, 2017) as it eases access to the transport services. Globally, feeder shuttle service is the most common method used to encourage rail ridership (Anspacher, Khattak, \& Yim, 2005) as it connects different modes of transportation (Bachok \& Zin, 2017) and considered the supplementary role required for sustainable development of urban transit system (Hu et al., 2012), while feeder routes serve as linkage between local areas (demand) with main transit networks (Ciaffi, Cipriani, \& Petrelli, 2012). In brief, integrating bus service facilities and features with urban rail transit services could bring significant benefits to the development of urban public transportation systems.

\section{PAST STUDIES OF CATCHMENT AREA CONCEPT}

In past studies, catchment areas had been defined in several ways. The most common definition is the distance that a pedestrian is willing to walk to access the transit (Flamm \& Rivasplata, 2014; Jiang, Zegras, \& Mehndiratta, 2012). The fundamental distance thresholds of $400 \mathrm{~m}$ (1/4 mile) and $800 \mathrm{~m}(1 / 2 \mathrm{mile})$ of pedestrian catchment areas were used as these are the acceptable walking distance (El-geneidy, Grimsrud, \& Rania, 2014; Guerra, Cervero, \& Tischler, 2012). A radial-based catchment area was widely used (Guerra et al., 2012) in transportation planning practices, for example, a service area analysis of stop's coverage was conducted by Tabassum et al. (2017) to estimate the number of people that were able to use the service within walking distance.

In Malaysian context, the Green Neighbourhood Guidelines developed by the Federal Department of Town and Country Planning (FDTCP) states that for human mobility within a neighbourhood, common facilities such as bus stops are 
Yakin Nur Sunoto, Zakiah Ponrahono, Zulfa Hanan Ash'aari, Nur Aulia Rosni, Noor Suzilawati Rabe, Nur Shazreena Mat Shukri, Wan Noratikah Wahidah Wan Ghazali

The Influence of Land Use Activities Towards Mass Rapid Transit (MRT) Feeder Bus Service Ridership

to be situated in walkable locations that are within $400 \mathrm{~m}$ or a five-minute walk, and transit stations are to be situated within $800 \mathrm{~m}$ or a ten-minute walk. Thus, in this study, the catchment area is measured at $200 \mathrm{~m}$ and $400 \mathrm{~m}$ radial distance from each bus stop. This scale is chosen based on previous research by Azmi and Karim (2012) and Sukor and Fisal (2018) on public transport users' willingness to walk in Malaysian cities. However, willingness to walk is also associated with land use activities and the environment.

A more clustered land use has higher possibility to attract public transportation users with lesser widespread public transportation networks, thus curbing the urban sprawl (Vos, 2015). According to Gu, Hickman, and Tong (2013) different land uses have different effects on the demand of public transportation and Stojanovski (2018) found land use diversity positively results in more passengers boarding the buses. Nevertheless, transit ridership is limited by the number of people working or living within the catchment area (Flamm \& Rivasplata, 2014), for example, only $30 \%$ from the number of residents and jobs contribute to bus patronage (Stojanovski, 2018). Hu, Fille, Khoon, Guang, and Monterola (2016) investigated the relationship between land use and public transportation ridership. By identifying the boarding and alighting rate for each locality and the land use data parcel around each transportation point, the transportation demand at a certain point provide information on its role in the entire system (Hu, Fille, Khoon, Guang, \& Monterola, 2016). Therefore, in this study, the number of passenger ingress at each bus stop were identified and related to existing land use activities.

\section{METHODS}

Site selection

Kajang was selected due to its highest population and density within the whole district. Kajang MRT Station serves as the first or last station for the MRT Sungai Buloh-Kajang line and acts as an interchange station with another rail line service which is KTM commuter (Kajang Station). Four feeder buses served the Kajang MRT Station: i) T461 Taman Kajang Utama; ii) T462 Seksyen 4 Bandar Baru Bangi; iii) T463 Seksyen 8 Bandar Baru Bangi; and iv) T464 Teras Jernang.

\section{Bus stops marking and route tracking}

The existing bus stop signages or shelters for each bus stop in all routes were identified on site and their locations were marked into a GPS device. Locations of passenger waiting areas without signages were marked based on information given by bus drivers. The collected bus stop coordinates were used as reference points when recreating bus stop points for the actual data analysis process. 


\section{Land use analysis}

Land use data around $200 \mathrm{~m}$ and $400 \mathrm{~m}$ radius from bus stops were used for the catchment area analysis in this study. Land use activities were recategorized to simplify the interpretation of land use composition around bus stops, while ensuring the significance of each land use throughout the data analysis process without excluding any land use activities. The listed 36 land use activities identified by local authority were regroup into 11 main land use categories for the purpose of bus stops catchment analysis (refer legend in Figure 2). Land use around a bus stop was identified through GIS spatial analysis by generating bus stop buffers. Figure 1 shows the flow of technique used to demarcate the buffer zone from bus stops and to obtain land use composition by using query expressions in ArcGIS 10.7.

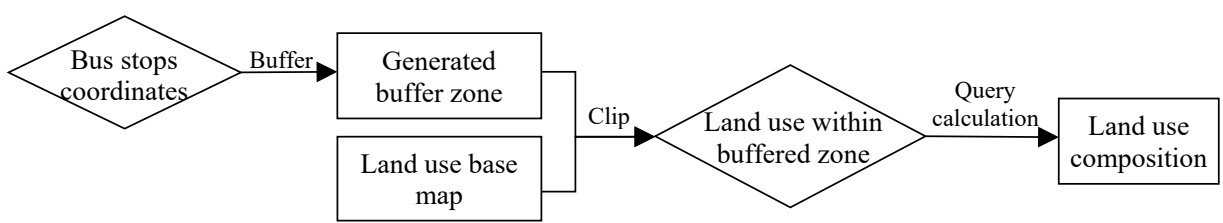

Figure 1: Flow of techniques used in demarcating buffer zone and calculating land use composition.

\section{On-board survey}

On-board observation was conducted to collect the data of passenger ingress at each bus stop during the whole journey for each trip selected. The data was collected on three weekdays and two weekends. For each day, at least 15 trips were selected and observed at each route including peak and off-peak hours. The data presented in this paper was collected in early 2020 .

\section{FINDINGS AND DISCUSSION}

\section{Land use activities and composition}

Catchment along the full route was not conducted in this study because it might not fully reflect the whole catchment area as the distance between one bus stop to another varies and might be longer than the acceptable walking distance. This could introduce gaps in the route's catchment area and reduce the willingness to walk to access feeder bus services (bus stops). Therefore, the overlapping buffer of $200 \mathrm{~m}$ and $400 \mathrm{~m}$ from each bus stop within all routes were merged into one continuous buffer representing the catchment area as a whole. Figure $\mathbf{2}$ shows the catchment area for all four feeder bus routes served by Kajang MRT Station which approximately covers an area of $1775 \mathrm{ha}$. The catchment areas served by these routes mostly travel southward from Kajang MRT Station with T464 route serving the farthest route. This route also covers the Kajang Town located at the north side of Kajang MRT Station. 
Yakin Nur Sunoto, Zakiah Ponrahono, Zulfa Hanan Ash'aari, Nur Aulia Rosni, Noor Suzilawati Rabe, Nur Shazreena Mat Shukri, Wan Noratikah Wahidah Wan Ghazali

The Influence of Land Use Activities Towards Mass Rapid Transit (MRT) Feeder Bus Service Ridership

Figure 3 shows the total land use covered by activities within the $200 \mathrm{~m}$ and 400 $\mathrm{m}$ service catchment areas. In both buffer zones, the highest land use covered is transportation namely road and railway which is excluded from this discussion. While road and railway are important for connectivity and accessibility in transportation network study, this study focuses on land uses that can potentially generate passengers. Therefore, within $200 \mathrm{~m}$ buffer, the highest land use activities covered is residential $(24.11 \%)$, followed by institution and public facilities $(12.26 \%)$, and open spaces and recreational (10.14\%).

Similar proportion of land use activities covered is shown in Figure 3 within buffer of $400 \mathrm{~m}$ with the highest being residential (24.21\%), followed by institution and public facilities $(12.99 \%)$, and open spaces and recreational (13.97\%). In overall, almost three quarter of land use covered by all routes are trip generation and attraction areas that are capable of inducing higher number of feeder bus users.

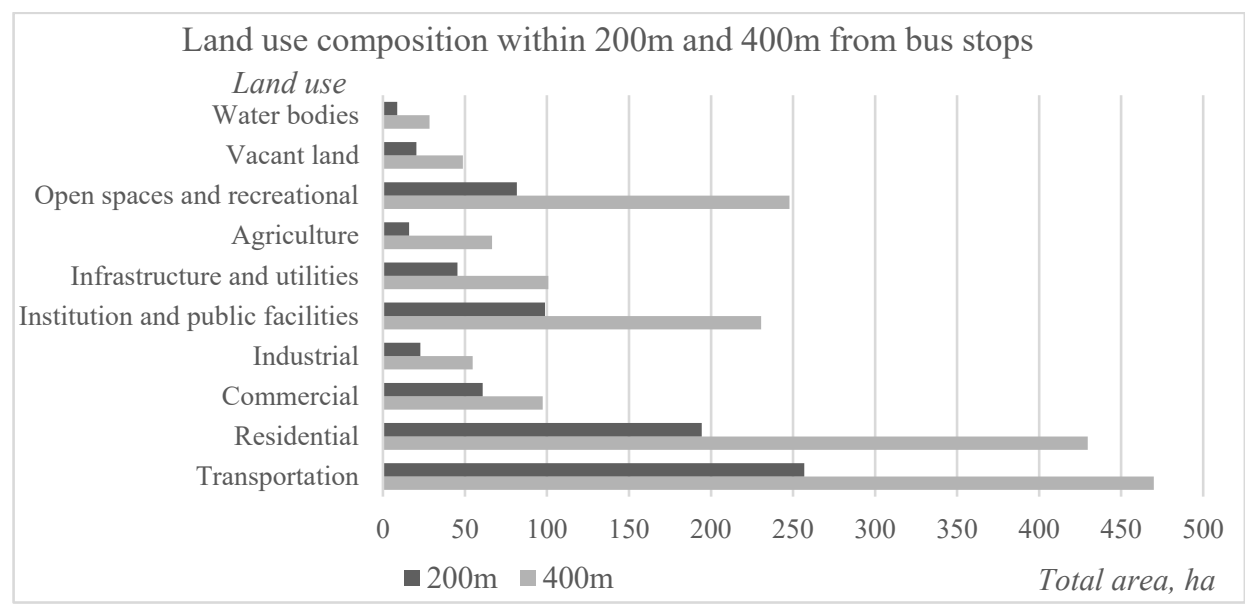

Figure 3: Total area of each land use activities within $200 \mathrm{~m}$ and $400 \mathrm{~m}$ of service catchment area 
PLANNING MALAYSIA

Journal of the Malaysia Institute of Planners (2021)

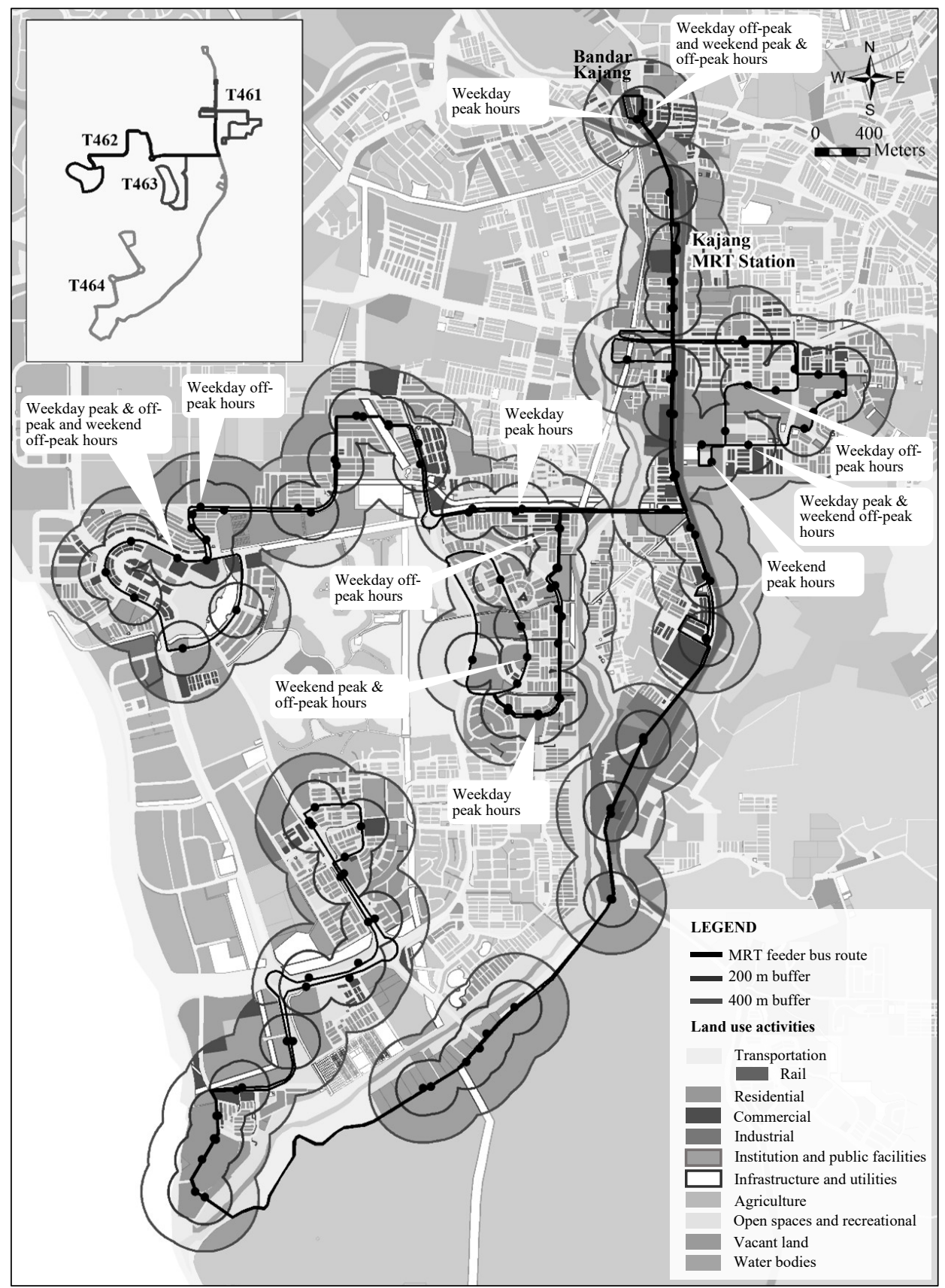

Figure 2: Land use activities around MRT feeder bus stops within $200 \mathrm{~m}$ and $400 \mathrm{~m}$ service catchment area 
Yakin Nur Sunoto, Zakiah Ponrahono, Zulfa Hanan Ash'aari, Nur Aulia Rosni, Noor Suzilawati Rabe, Nur Shazreena Mat Shukri, Wan Noratikah Wahidah Wan Ghazali

The Influence of Land Use Activities Towards Mass Rapid Transit (MRT) Feeder Bus Service Ridership

In practice, housing area is one of the trip or passenger generation areas in land use and ridership studies especially during morning trips where passengers commute to work and attraction areas such as location of activities. High density residential and commercial areas are said to be significant in promoting the propensity to walk as these areas have convenient environment (Kang, Jayaraman, \& Keng, 2013; Abdul Aziz, 2014; Norhisham, Syamsir, Abu Bakar, \& Ramli, 2020).

\section{Highest passenger ingress}

To study the demand at each bus stop, this study only extracts the highest number of passenger ingress at each bus stop on weekdays and weekends during both peak and off-peak hours. The origin (Kajang MRT Station) of route T461, T462, T463, and bus stop at Kajang MRT Station in route T464 were excluded from the analysis of land use activities at bus stop along the routes. Figure $\mathbf{4}$ to Figure $\mathbf{7}$ show the highest demand at each bus stop along all four routes during weekdays and weekends. Figure 2 portrays each location of bus stops (and details of land use activities around bus stops) mentioned in the following paragraphs.

Based on Figure 4, the highest number of passenger ingress at route T461 during peak hours is eight passengers at bus stop 9 (Perumahan Seksyen 2) on weekdays and seven passengers at bus stop 7 (Flat Citra) on weekends. On the other hand, the highest number recorded at route T461 during off-peak hours is nine passengers at bus stop 5 (SK Kajang Utama) on weekdays and seven passengers at bus stop 9 (Perumahan Seksyen 2) on weekends. Since these bus stops serve residential areas and educational institutions and services, there is demand even after peak hours.

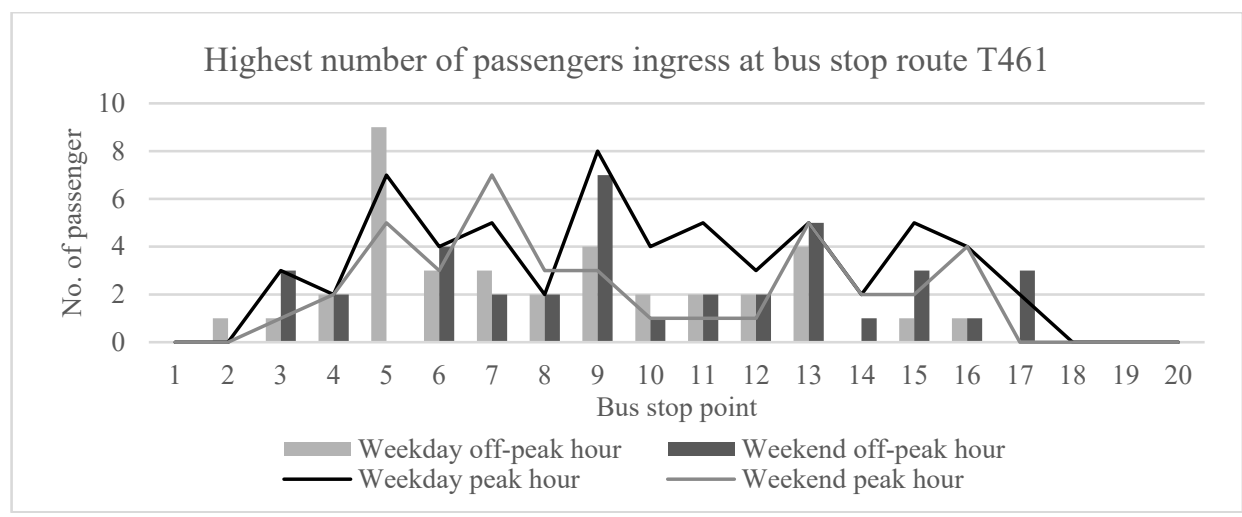

Figure 4: Highest number of passenger ingress at each bus stop route T461 during peak and off-peak hour 
The highest number of passenger ingress at route T462 (Figure 5) during peak hours is eight passengers at bus stop 6 (Komersial Seksyen 4 Tambahan) on weekdays and six passengers at bus stop 17 (Kompleks PKNS Bangi) on weekends. In contrary, the highest number of passenger ingress during off-peak hours is only four passengers at bus stops 5 (Reko Sentral (Opp)), 17 (Kompleks PKNS Bangi), and 25 (Seksyen 8 Fasa 2) on weekdays, and five passengers at bus stop 17 (Kompleks PKNS Bangi) on weekends. These bus stops generate higher demand than the other areas along route T462 during peak and off-peak hours due to the presence of commercial areas and shopping complexes near these bus stops. Kang, Jayaraman, and Keng (2013) also suggested that good feeder routes should serve areas with common focal activities such as shopping malls, schools, and commercial centres.

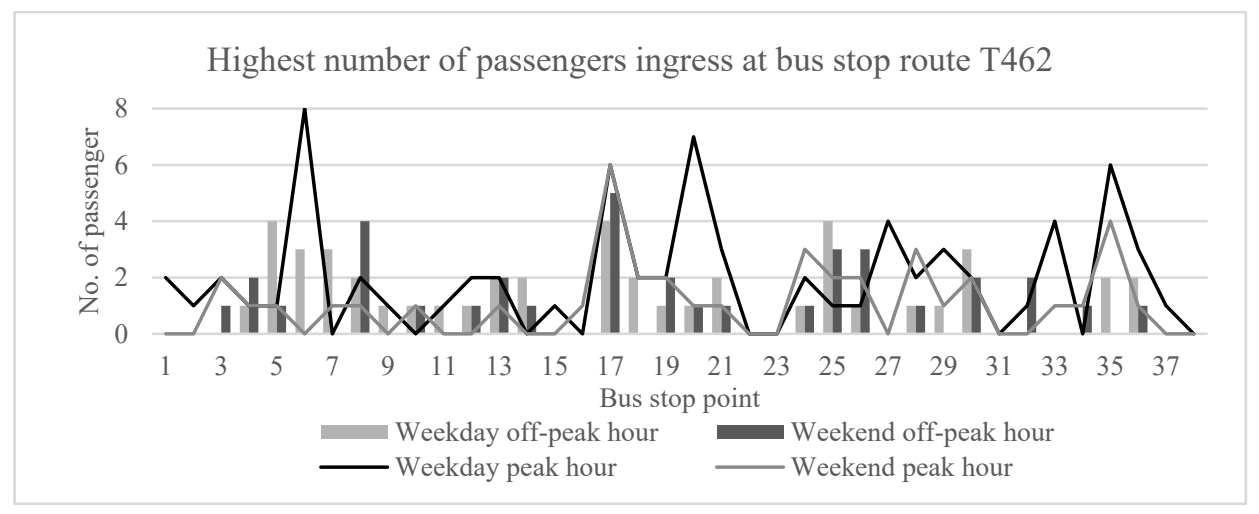

Figure 5: Highest number of passenger ingress at each bus stop route T462 during peak and off-peak hour

Based on Figure 6, the highest number of passenger ingress at route T463 during peak hours is six passengers at bus stop 11 (SK Jalan Ampat) on weekdays and eight passengers at bus stop 14 (Pangsapuri Anggun) on weekends. The highest number of passenger ingress at route T461 during off-peak hours is only four passengers at bus stops 24 (SMK Jalan Ampat (Back-Opp)) on weekdays and 11 passengers at bus stop 14 (Pangsapuri Anggun) on weekends. Bus stop 14 shows the highest number of passenger ingress both during weekdays and weekends but at different time frames. Similar to route T461, this route serves residential areas and educational institutions. Norhisham, Syamsir, Abu Bakar, and Ramli (2020) also found similar outcome of higher ridership at routes that serve these land use activities. 
Yakin Nur Sunoto, Zakiah Ponrahono, Zulfa Hanan Ash'aari, Nur Aulia Rosni, Noor Suzilawati Rabe, Nur Shazreena Mat Shukri, Wan Noratikah Wahidah Wan Ghazali

The Influence of Land Use Activities Towards Mass Rapid Transit (MRT) Feeder Bus Service Ridership

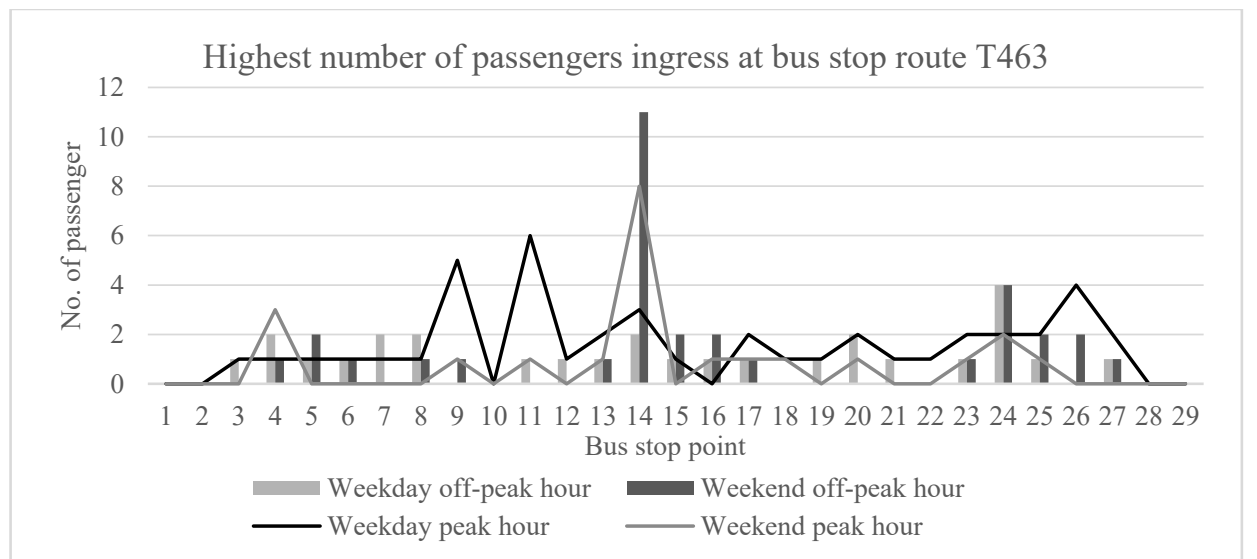

Figure 6: Highest number of passenger ingress at each bus stop route T463 during peak and off-peak hour

Based on Figure 7, the highest number of passenger ingress at route T464 during peak hours is 11 and 20 passengers at bus stop 29 and 30 in Kajang Town on weekends. Similarly, the highest numbers of passenger ingress for this route during off-peak hours at bus stop 30 (Bandar Kajang) are 13 and 12 passengers on weekday and weekend, respectively. Bus stops 29 and 30 show the highest number of passenger ingress on both weekday and weekend period but at different time frames as these two bus stops are located in Kajang city and T464 is the only route among the other three routes that serves up till Kajang city. T464 proves that it has a longer service area to suburban residences, thus overcoming the issue of low access at residential areas and providing access to town areas (Abdul Aziz, 2014).

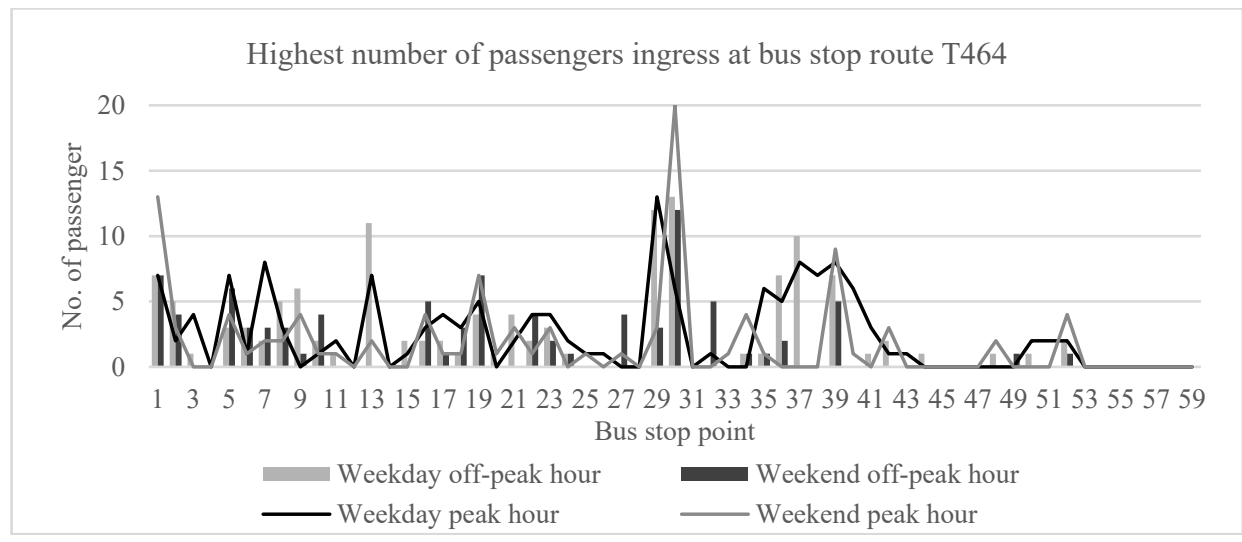

Figure 7: Highest number of passenger ingress at each bus stop route T464 during peak and off-peak hour 
In average, the findings of passenger ingress in this study clearly show that the demand for MRT feeder bus at each bus stop along each route is below five passengers regardless of land use activities. We assume that the declining number of passengers at bus stops close to the MRT station is due to existing overlapping services by other bus service operators and among the MRT feeder bus itself, providing passengers better options to ride any bus that arrives first. Apart from that, it should be noted that not all passengers who ride these MRT feeder buses have the intention to access the MRT Kajang rail service as some of them egress earlier at other bus stops along the routes. Therefore, feeder bus is not only important for some passengers as their first and/or last mile mode of transportation to complete their trips, but also simply as the mode of transfer between bus stops.

In addition, the overlapping buffer presented in this study does not necessarily mean that it is accessible especially by walking because the accessible area could be smaller as barriers such as high-elevated road dividers discourage user's movement from one side of the road to the other. In most cases in this study, bus stops are provided at both sides of the road to increase user convenience and options of ingress or egress points. Currently, there is no overhead pedestrian bridge that connects Kajang MRT Station to the other side of road, and this may reduce accessibility of users to the station.

\section{CONCLUSION}

In conclusion, land use activities that exist around bus stops had influence on the feeder bus ridership. Even though the analysis involves percentage composition as part of the interpretation, it does not reflect the whole situation in the real world, as the passengers demand also depends on other land use attributes such as land use density. Coverage of land use activities alone is not enough because the density of population that resides or works varies between each activity. For example, industrial or commercial areas may experience higher demand during working hours, while residential areas may generate more passengers during the early period and end of the day. This limitation could be overcome if other land use attributes were included during analysis. However, since this study aims to evaluate the current demand, understanding the existing land use activities is adequate.

\section{ACKNOWLEDGEMENT}

This research was fully supported by Putra Grant UPM - Putra Young Initiative (GP-IPM/2018/9592500). 
Yakin Nur Sunoto, Zakiah Ponrahono, Zulfa Hanan Ash'aari, Nur Aulia Rosni, Noor Suzilawati Rabe, Nur Shazreena Mat Shukri, Wan Noratikah Wahidah Wan Ghazali

The Influence of Land Use Activities Towards Mass Rapid Transit (MRT) Feeder Bus Service Ridership

\section{REFERENCES}

Abdul Aziz, A. (2014, October 13). Development and Improvement of Land Public Trasnsportation: The Malaysian Experience.

Anspacher, D., Khattak, A. J., \& Yim, Y. (2005). The demand for rail feeder shuttles. Journal of Public Transportation, 8(1), 1-20.

Bachok, S., \& Zin, S. H. M. M. (2017). Feeder mode choice selection behavioural modelling: The case of KTM Komuter, Kuala Lumpur. Journal of the Malaysian Institute of Planners, 15(1), 65-80.

Chakraborty, A., \& Mishra, S. (2013). Land Use Policy Land use and transit ridership connections: Implications for state-level planning agencies. Land Use Policy, 30(1), 458-469. https://doi.org/10.1016/j.landusepol.2012.04.017

Chen, X., Shan, X., Ye, J., Yi, F., \& Wang, Y. (2017). Evaluating the effects of traffic congestion and passenger load on feeder bus fuel and emissions compared with passenger car. Transportation Research Procedia, 25, 616-626. https://doi.org/10.1016/j.trpro.2017.05.446

Ciaffi, F., Cipriani, E., \& Petrelli, M. (2012). Feeder Bus Network Design Problem: a New Metaheuristic Procedure and Real Size Applications. Procedia - Social and Behavioral Sciences, 54, 798-807. https://doi.org/10.1016/j.sbspro.2012.09.796

Clifton, G., \& Mulley, C. (2018). Barriers and facilitators of integration between buses with a higher level of service and rail: An Australian case study. Research in Transportation Economics, (July), 1-12. https://doi.org/10.1016/j.retrec.2018.07.027

Colonna, P., Berloco, N., \& Circella, G. (2012). The Interaction between Land Use and Transport Planning: A Methodological Issue. Procedia - Social and Behavioral Sciences, 53, 84-95. https://doi.org/10.1016/J.SBSPRO.2012.09.862

El-geneidy, A. M., Grimsrud, M., \& Rania, W. (2014). New evidence on walking distances to transit stops: Identifying redundancies and gaps using variable service areas New evidence on walking distances to transit stops : Identifying redundancies and gaps using variable service areas. (November 2019). https://doi.org/10.1007/s11116-013-9508-z

Flamm, B. J., \& Rivasplata, C. R. (2014). Public Transit Catchment Areas The Curious Case of Cycle - Transit Users. Journal of the Transportation Research Board, 101-108. https://doi.org/10.3141/2419-10

Guerra, E., Cervero, R., \& Tischler, D. (2012). Half-Mile Circle. Transport Reseach Record, (2276), 101-109. https://doi.org/10.3141/2276-12

Hu, N., Fille, E., Khoon, K., Guang, G., \& Monterola, C. (2016). Impacts of land use and amenities on public transport use, urban planning and design. Land Use Policy, 57, 356-367. https://doi.org/10.1016/j.landusepol.2016.06.004

Hu, Y., Zhang, Q., \& Wang, W. (2012). A Model Layout Region Optimization for Feeder Buses of Rail Transit. Procedia - Social and Behavioral Sciences, 43, 773-780. https://doi.org/10.1016/j.sbspro.2012.04.151

Jiang, Y., Zegras, P. C., \& Mehndiratta, S. (2012). Walk the line: Station context, corridor type and bus rapid transit walk access in Jinan, China. Journal of Transport Geography, 20(1), 1-14. https://doi.org/10.1016/j.jtrangeo.2011.09.007 
Kang, S. A., Jayaraman, K., \& Keng, L. (2013). Road congestion, vehicles emissions and the intention to use public bus services in Malaysia - A flexible bus utility model . World Transport Policy and Practice, 19.1, 8-24.

Land Public Transport Commission (SPAD). (2012). National Land Public Transport Masterplan. Kuala Lumpur: Land and Public Transport Commision.

Litman, T. (2008). Valuing Transit Service Quality Improvements. Journal of Public Transportation, 11(2), 43-63. Retrieved from https://www.nctr.usf.edu/jpt/pdf/JPT11-2Litman.pdf

Norhisham, S., Syamsir, A., Abu Bakar, M. F., \& Ramli, M. Z. (2020). Evaluating Passenger Load Factor of Public Bus Services in West Klang Valley. ICACE 2019, 95-102.

Stojanovski, T. (2018). How density, diversity, land use and neighborhood type influences bus mobility in the Swedish city of Karlstad: Mixing spatial analytic and typo-morphological approaches to assess the indirect effect of urban form on travel. 769-789.

Sung, H., Choi, K., Lee, S., \& Cheon, S. (2014). Exploring the impacts of land use by service coverage and station-level accessibility on rail transit ridership. Journal of $\begin{array}{llll}\text { Transport } \quad \text { Geography, } & \text { 136-140. }\end{array}$ https://doi.org/10.1016/j.jtrangeo.2014.03.013

Tabassum, S., Tanaka, S., Nakamura, F., \& Ryo, A. (2017). Feeder Network Design for Mass Transit System in Developing Countries (Case study of Lahore, Pakistan). Transportation Research Procedia. https://doi.org/10.1016/j.trpro.2017.05.343

Vos, J. De. (2015). The influence of land use and mobility policy on travel behavior : A comparative case study of Flanders and the Netherlands. The Journal of Transport $\begin{array}{llll}\text { and } \quad \text { Land } & \text { Use, } & \text { 171-190. }\end{array}$ https://doi.org/http://dx.doi.org/10.5198/jtlu.2015.709

Zuo, T., Wei, H., \& Rohne, A. (2018). Determining transit service coverage by nonmotorized accessibility to transit : Case study of applying GPS data in Cincinnati metropolitan area. Journal of Transport Geography, 67, 1-11. https://doi.org/10.1016/j.jtrangeo.2018.01.002

Received: $13^{\text {th }}$ August 2021. Accepted: $13^{\text {th }}$ October 2021 